\title{
Response of respiration and nutrient availability to drying and rewetting in soil from a semi-arid woodland depends on vegetation patch and a recent wildfire
}

\author{
Q. Sun ${ }^{1}$, W. S. Meyer ${ }^{1}$, G. R. Koerber ${ }^{1}$, and P. Marschner ${ }^{2}$ \\ ${ }^{1}$ Department of Ecology and Environmental Science, School of Biological Sciences, The University of Adelaide, Adelaide, \\ SA 5005, Australia \\ ${ }^{2}$ Soils, School of Agriculture, Food and Wine, The University of Adelaide, Adelaide, SA 5005, Australia
}

Correspondence to: Q. Sun (qiaoqi.sun@adelaide.edu.au)

Received: 16 April 2015 - Published in Biogeosciences Discuss.: 12 June 2015

Accepted: 18 August 2015 - Published: 27 August 2015

\begin{abstract}
Semi-arid woodlands, which are characterised by patchy vegetation interspersed with bare, open areas, are frequently exposed to wildfire. During summer, long dry periods are occasionally interrupted by rainfall events. It is well known that rewetting of dry soil induces a flush of respiration. However, the magnitude of the flush may differ between vegetation patches and open areas because of different organic matter content, which could be further modulated by wildfire. Soils were collected from under trees, under shrubs or in open areas in unburnt and burnt sandy mallee woodland, where part of the woodland experienced a wildfire which destroyed or damaged most of the aboveground plant parts 4 months before sampling. In an incubation experiment, the soils were exposed to two moisture treatments: constantly moist (CM) and drying and rewetting (DRW). In CM, soils were incubated at $80 \%$ of maximum water holding capacity (WHC) for 19 days; in DRW, soils were dried for 4 days, kept dry for another 5 days, then rewetted to $80 \%$ WHC and maintained at this water content until day 19 . Soil respiration decreased during drying and was very low in the dry period; rewetting induced a respiration flush. Compared to soil under shrubs and in open areas, cumulative respiration per gram of soil in CM and DRW was greater under trees, but lower when expressed per gram of total organic carbon (TOC). Organic matter content, available $\mathrm{P}$, and microbial biomass $\mathrm{C}$, but not available $\mathrm{N}$, were greater under trees than in open areas. Wild fire decreased the flush of respiration per gram of TOC in the open areas and under shrubs, and reduced TOC and microbial biomass $\mathrm{C}$ (MBC) concentrations only
\end{abstract}

under trees, but had little effect on available $\mathrm{N}$ and $\mathrm{P}$ concentrations. We conclude that the impact of wildfire and DRW events on nutrient cycling differs among vegetation patches of a native semi-arid woodland which is related to organic matter amount and availability.

\section{Introduction}

Semi-arid woodlands are widespread in regions with Mediterranean climate where, in summer, long dry periods are occasionally interrupted by heavy rainfall events. Rewetting of dry soil induces a flush of respiration, which has been explained by increased substrate availability due to death of part of the microbial biomass, release of osmolytes accumulated during the dry period, and exposure of previously occluded organic matter (Fierer and Schimel, 2002; NavarroGarcia et al., 2012; Kim et al., 2012; Borken and Matzner, 2009; Birch, 1958). In dry ecosystems, the respiration pulse upon rewetting may contribute a significant proportion of the total annual $\mathrm{CO}_{2}$ flux from surface soils (Fierer and Schimel, 2003; Jarvis et al., 2007).

The size of the rewetting flush is determined by concentration, availability and distribution of organic carbon (e.g. Butterly et al., 2010; Franzluebbers et al., 2000), and soil water content before rewetting (e.g. Xu et al., 2004; Chowdhury et al., 2011). In semi-arid woodlands, vegetation cover is highly variable, with large patches of bare ground between vegetation patches, resulting in large spatial variations in $\mathrm{C}, \mathrm{N}$ and 
P concentrations (e.g. Lal, 2004; Schlesinger and Pilmanis, 1998). Generally soils under vegetation canopies have higher organic carbon (OC) content than interspaces because of the greater C input (White et al., 2009).

Semi-arid woodlands are frequently exposed to fire, which changes not only vegetation structure and communities but also soil properties such as reducing soil organic matter content and increasing recalcitrance of the remaining organic matter (Fernandez et al., 1999; Hatten and Zabowski, 2009). These changes in soil organic matter content and recalcitrance could also influence the response of respiration to drying and rewetting.

The aim of this study was to determine the effect of a recent wildfire on the response of soil respiration and microbial biomass in soils from different vegetation patches of a semiarid woodland on nutrient-poor sandy soil. We hypothesised that (i) the flush of respiration after rewetting will be greater in patches with greater total organic carbon (TOC) concentration and that (ii) burning will reduce soil respiration in all patches irrespective of moisture treatment.

\section{Materials and methods}

\subsection{Site description and soil sampling}

The study site was at Calperum Station, next to the Chowilla floodplain of the River Murray near Renmark in the western part of the Murray Basin in south-eastern Australia. This area is the largest (over 1 million hectares), continuous remnant of mallee habitat in Australia (Nulsen et al., 1986). The mallee woodland is a shrub-eucalypt association, including woodlands of four dominant eucalypt species (Eucalyptus dumosa, E. incrassata, E. oleosa and E. socialis) and extensive shrublands of spinifex (Triodia basedowii).

The area is semi-arid with $251 \mathrm{~mm}$ mean annual rainfall and a mean air temperature of $25^{\circ} \mathrm{C}$ (data accessed from http: //www.bom.gov.au/). Air temperatures of $>40^{\circ} \mathrm{C}$ or higher are common in summer. The sandy soil ( $2 \%$ clay, $4 \%$ silt and $94 \%$ sand) has a bulk density of $1.6 \mathrm{~g} \mathrm{~cm}^{-3}$ in $0-30 \mathrm{~cm}$ depth, and is classified as Tenosol in the Australian Soil Classification (Isbell, 2002), and as Aridisol in the US Soil Taxonomy (Soil Survey Staff, 1996). A recent wildfire (from 15 to 19 January 2014) burnt part of the woodland. The fuel load for fires in this ecosystem is primarily the spinifex grass clumps and the bark and leaf litter on the soil surface. Due to high temperature, low humidity and high winds in midJanuary, the wildfire rapidly consumed the ground-based fuel and spread into the mallee tree canopies. Foliage on the trees was either burnt completely or killed by the high temperatures. Instruments, located up to $10 \mathrm{~m}$ from the ground on a flux tower at the site, were destroyed by the radiant heat.

Four months after the fire, two locations were sampled: unburnt $\left(34^{\circ} 0^{\prime} 48.78^{\prime \prime} \mathrm{S}, 140^{\circ} 35^{\prime} 33.65^{\prime \prime} \mathrm{E}\right)$ and burnt mallee $\left(34^{\circ} 0^{\prime} 6.34^{\prime \prime} \mathrm{S}, 140^{\circ} 35^{\prime} 14.99^{\prime \prime} \mathrm{E}\right)$ woodland, which are about
$2 \mathrm{~km}$ apart from each other. During the 4 months after the fire, the daily maximum temperatures remained $>30^{\circ} \mathrm{C}$ with occasional light $(<3 \mathrm{~mm})$ rainfall events. Within each location, after removal of the litter layer, soil from 0 to $30 \mathrm{~cm}$ depth was collected underneath patches of eucalyptus (hereafter referred to as "tree") and patches of spinifex (referred to as "shrub"), as well as from open areas between vegetation patches (referred to as "open"). The open areas were completely bare patches without litter or living plants aboveground. Within burnt and unburnt mallee, three transects $>50 \mathrm{~m}$ apart from each other were randomly selected. Three samples underneath trees and shrubs and in open areas were taken along each transect. The three samples from a given patch were then combined, mixed and sieved to $<2 \mathrm{~mm}$ and air-dried at $30^{\circ} \mathrm{C}$. The composite sample was subsampled to give the four replicates in the experiment. In this semi-arid region with high summer temperatures and little annual rainfall on sandy, rapidly draining soils, top soils are air-dry most of the time.

\subsection{Experimental design and methods}

The air-dried soil was pre-incubated for 14 days at $25^{\circ} \mathrm{C}$ at $80 \%$ of water holding capacity (WHC) to reactivate the microbes at the beginning of the experiment. During preincubation soil respiration rate was stable after 10 days (data not shown). The water content of $80 \%$ WHC was chosen because, in a preliminary experiment with different water contents, cumulative soil respiration after 10 days was maximal at $80 \%$ of WHC (unpublished data).

After pre-incubation, $25 \mathrm{~g}$ dry weight equivalent of pre-incubated soil was packed into PVC cores $(37 \mathrm{~mm}$ ID $\times 50 \mathrm{~mm}$ height $)$ with a nylon mesh bottom $(0.75 \mu \mathrm{m}$, Australian Filter Specialists) and then subjected to either CM or DRW treatments. Soil height in the cores was adjusted to achieve the field soil bulk density. Then the cores were transferred to $250 \mathrm{~mL}$ glass jars (Ball ${ }^{\circledR}$ half-pint wide-mouth jars, Jarden Corporation) fitted with gas-tight lids which had stainless steel septum ports with rubber septa to allow sampling of headspace.

Half of the cores were maintained at $80 \%$ WHC throughout the experiment. The other half of the soil cores were dried within 4 days $(<0.03 \mathrm{~g}$ water per gram of soil $)$, then kept dry for the next 5 days, and then rewetted to $80 \%$ WHC, after which they were maintained at this water content until the end of the experiment (day 19). Within the drying period of 4 days, the water content gradually decreased but then remained stable. The experiment was stopped when the respiration rate after rewetting was stable for at least 2 days. To induce rapid drying, a cotton pouch $(60 \times 60 \mathrm{~mm})$ containing $8 \mathrm{~g}$ of self-indicating silica gel (BDH Chemical, England) was added to each jar and changed daily until the end of the drying period. The silica gel remained in the jars during the dry period. For regeneration of the silica, the pouches were dried at $75^{\circ} \mathrm{C}$ overnight. After removal of the silica pouches 
on day 9 , the soil was rewetted to $80 \%$ of WHC by adding reverse osmosis (RO) water added slowly in a circular motion to ensure uniform wetting. To minimise water loss from the soil in the CM treatment or after rewetting, vials with $7 \mathrm{~mL}$ of reverse osmosis (RO) water were placed into the jars. In total, there were 48 cores (two locations, three patches, two moisture treatments and four replicates).

Soil respiration was measured daily. Soil $\mathrm{pH}$ and TOC was measured in air-dried soils. Microbial biomass $\mathrm{C}$ and available $\mathrm{N}$ and $\mathrm{P}$ were measured at the start (after pre-incubation) and the end of the experiment (day 19).

Maximum WHC was measured using a sintered glass funnel connected to a $100 \mathrm{~cm}$ water column $\left(\psi_{\mathrm{m}}=-10 \mathrm{kPa}\right)$. The soils were placed in rings in the sintered glass funnel, thoroughly wetted, covered and allowed to drain for $>48 \mathrm{~h}$, after which gravimetric water content was determined (Wilke, 2005). Soil $\mathrm{pH}$ was measured in a $1: 5$ soil: water suspension after $1 \mathrm{~h}$ of end-over-end shaking at $25^{\circ} \mathrm{C}$ (Rayment and Higginson, 1992). TOC content was measured by wet oxidation (Walkley and Black, 1934). Soil respiration was quantified using a Servomex 1450 infrared gas analyser (Servomex Group, Crowborough, England), as described by Setia et al. (2011). After each measurement, the jars were opened to refresh the headspace in the jars using a fan to maximise air exchange. Known amounts of $\mathrm{CO}_{2}$ were injected into empty glass jars of similar volume to establish a linear regression between $\mathrm{CO}_{2}$ concentration and detector reading. Cumulative respiration expressed per gram of soil is strongly influenced by TOC content. To estimate OC decomposability, we expressed soil respiration rate and cumulative respiration per gram of TOC. Available N (nitrate + ammonium) was determined after $1 \mathrm{~h}$ of mixing the soil sample in an end-over-end shaker with $2 \mathrm{M} \mathrm{KCl}$ with a soil : extractant ratio of $1: 5$. Nitrate $\mathrm{N}$ was measured based on the method modified by Miranda et al. (2001) and ammonium N concentration as described in Forster (1995). Available $\mathrm{P}$ was determined by the anion exchange resin method (Kouno et al., 1995). Microbial biomass C (MBC) was measured by fumigation-extraction (Vance et al., 1987). Fumigated and unfumigated samples were extracted with $0.5 \mathrm{M}$ $\mathrm{K}_{2} \mathrm{SO}_{4}$ solution at a $1: 4$ soil: extractant ratio. After filtering through Whatman filter paper no. 42 , the OC concentration of the extracts was determined by titration with $0.033 \mathrm{M}$ acidified $\left(\mathrm{NH}_{4}\right)_{2} \mathrm{Fe}\left(\mathrm{SO}_{4}\right)_{2} \cdot 6 \mathrm{H}_{2} \mathrm{O}$ after dichromate oxidation (Anderson and Ingram, 1993). Microbial biomass carbon was calculated by subtracting the OC concentration of fumigated from unfumigated samples and multiplying the difference by 2.64 (Vance et al., 1987).

\subsection{Statistical analysis}

Two-way analysis of variance (ANOVA) with a post hoc Tukey test was used to determine effects of patch (under shrubs, in open areas and under trees) $\times$ burning (unburnt and burnt) on soil $\mathrm{pH}$, TOC content, and MBC and available nu- trient concentrations after pre-incubation (day 0). Data were also analysed by three-way ANOVA to determine effects of patch (under shrubs, in open areas and under trees), burning (unburnt and burnt) and moisture treatment (CM or DRW) and their interactions on respiration rate on day 1 after rewetting and for the following data from day 19 (end of the experiment): cumulative respiration per gram of soil and TOC, soil $\mathrm{MBC}$ and available nutrients. All statistical analyses were carried out with R software (R Development Core Team, 2013). Significance was set at $p<0.05$.

\section{Results}

\subsection{Soil properties}

In the unburnt soils, the $\mathrm{pH}$ was higher under shrubs than under trees or in the open areas, whereas the reverse was true in burnt soils (Table 1). Burning had no consistent effect on soil $\mathrm{pH}$. Compared to unburnt soils, the $\mathrm{pH}$ in the burnt mallee was lower under shrubs, higher under trees and had no effect in open areas. Soil WHC was greatest under trees of unburnt mallee but differed little among other patches. TOC content was higher under trees than in open areas or under shrubs. The difference in TOC content between soil under trees and the other two patches was greater in unburnt mallee (more than 5-fold) than in burnt soils (about 2-fold). Burning reduced the TOC content under trees by $50 \%$, but doubled it in the open areas and had no effect under shrubs.

\subsection{Respiration}

Respiration rate per gram of TOC decreased within 1 to 3 days after the onset of the drying period and then remained low until rewetting (Fig. 1). Rewetting of dry soil induced a flush of respiration with rates higher than the CM soils for 2 days. After this flush, respiration rates were similar in DRW and CM soils.

The respiration rate per gram of TOC on the first day after rewetting was two to 5-fold higher than it was in CM soils (Table 2 and Table A1). For both unburnt and burnt mallee, the increase in respiration rate per gram of TOC after rewetting compared to the $\mathrm{CM}$ soil was greater under shrubs and in open areas (2-3-fold) than under trees (2-fold). Respiration rates in the CM soil were similar in unburnt and burnt mallee, but the respiration rate on the first day after rewetting was significantly lower (by 40-90\%) in open areas and under shrubs of burnt than unburnt mallee.

Cumulative respiration per gram of soil on day 19 was greater under trees than in the other two patches (Fig. 2, Table A1). Drying and rewetting had little effect on cumulative respiration per gram of soil except under trees of unburnt mallee, where it was significantly higher in CM than DRW (by $30 \%$ ). Burning significantly reduced cumulative respiration under trees in both CM and DRW, but had no effect in the other patches. 
Table 1. Properties of unburnt and burnt mallee soils under shrubs and trees or in open areas (mean, $n=4$ for $\mathrm{pH}$ and TOC values, $n=2$ for water capacity data). For $\mathrm{pH}$ and TOC, different letters indicate significant differences for the burning $\times$ patch interaction at $p<0.05$.

\begin{tabular}{|c|c|c|c|c|c|c|}
\hline \multirow[t]{2}{*}{ Soil property } & \multicolumn{3}{|c|}{ Unburnt mallee } & \multicolumn{3}{|c|}{ Burnt mallee } \\
\hline & Shrub & Open & Tree & Shrub & Open & Tree \\
\hline $\mathrm{pH}_{1: 5}$ & $9.6^{\mathrm{a}}$ & $8.7^{\mathrm{b}}$ & $8.8^{\mathrm{b}}$ & $7.8^{\mathrm{c}}$ & $9.2^{\mathrm{ab}}$ & $9.5^{\mathrm{a}}$ \\
\hline Maximum water holding capacity ( $\mathrm{g}$ water $\mathrm{g}^{-1}$ soil) & 0.06 & 0.06 & 0.09 & 0.05 & 0.06 & 0.06 \\
\hline $\mathrm{TOC}\left(\mathrm{mg} \mathrm{C} \mathrm{g}^{-1}\right.$ soil $)$ & $2.00^{\mathrm{cd}}$ & $1.11^{\mathrm{e}}$ & $10.45^{\mathrm{a}}$ & $1.71^{\mathrm{de}}$ & $2.46^{\mathrm{c}}$ & $4.66^{\mathrm{b}}$ \\
\hline
\end{tabular}

Table 2. Soil respiration rate per gram of TOC and hour on day 1 after rewetting and that under the constantly treatment (mean \pm standard error, $n=4)$. Different letters indicate significant differences at $p<0.05$ for the three-way interaction patch $\times$ burning $\times$ moisture treatment.

\begin{tabular}{lcccc}
\hline \multirow{2}{*}{ Patch } & \multicolumn{4}{c}{ Soil respiration rate $\left(\mathrm{mg} \mathrm{CO}_{2}-\mathrm{Cg}^{-1} \mathrm{TOC}^{-1}\right)$} \\
\cline { 2 - 5 } & \multicolumn{3}{c}{ Burnt } \\
\hline & 1 st day after rewetting & Constantly moist & 1 st day after rewetting & Constantly moist \\
\hline Shrub & $0.43 \pm 0.01^{\mathrm{b}}$ & $0.10 \pm 0.01^{\mathrm{de}}$ & $0.29 \pm 0.01^{\mathrm{c}}$ & $0.06 \pm 0.01^{\mathrm{e}}$ \\
Open & $0.55 \pm 0.06^{\mathrm{a}}$ & $0.17 \pm 0.04^{\mathrm{de}}$ & $0.28 \pm 0.01^{\mathrm{c}}$ & $0.10 \pm 0.01^{\mathrm{de}}$ \\
Tree & $0.14 \pm 0.00^{\mathrm{de}}$ & $0.08 \pm 0.00^{\mathrm{e}}$ & $0.20 \pm 0.01^{\mathrm{cd}}$ & $0.08 \pm 0.01^{\mathrm{e}}$ \\
\hline
\end{tabular}

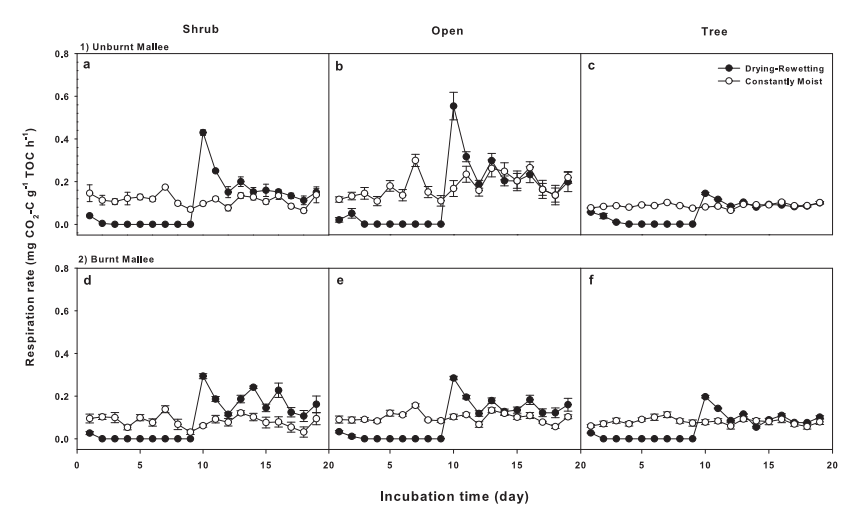

Figure 1. Soil respiration rate per gram of TOC in soil from under shrubs (a, d), in open areas $(\mathbf{b}, \mathbf{e})$ and under trees $(\mathbf{c}, \mathbf{f})$ and of unburnt (a-c) and burnt (d-f) mallee woodlands under constantly moist and dry-rewetting treatments (mean \pm standard error, $n=4$ ).

Cumulative respiration per gram of TOC on day 19 was not significantly influenced by soil moisture regime (Fig. 2, Table A1). In both CM and DRW, cumulative respiration per gram of TOC was greatest in open areas of unburnt mallee but differed little among other patches. Burning reduced cumulative respiration per gram of TOC only in open areas and only in CM (by about $40 \%$ ).

\subsection{Microbial biomass C}

The MBC concentration was higher under trees than under shrubs and in open areas (Fig. 3, Table A1). Burning decreased $\mathrm{MBC}$ concentrations on day 0 under trees by about $50 \%$ compared to unburnt mallee and increased MBC con-

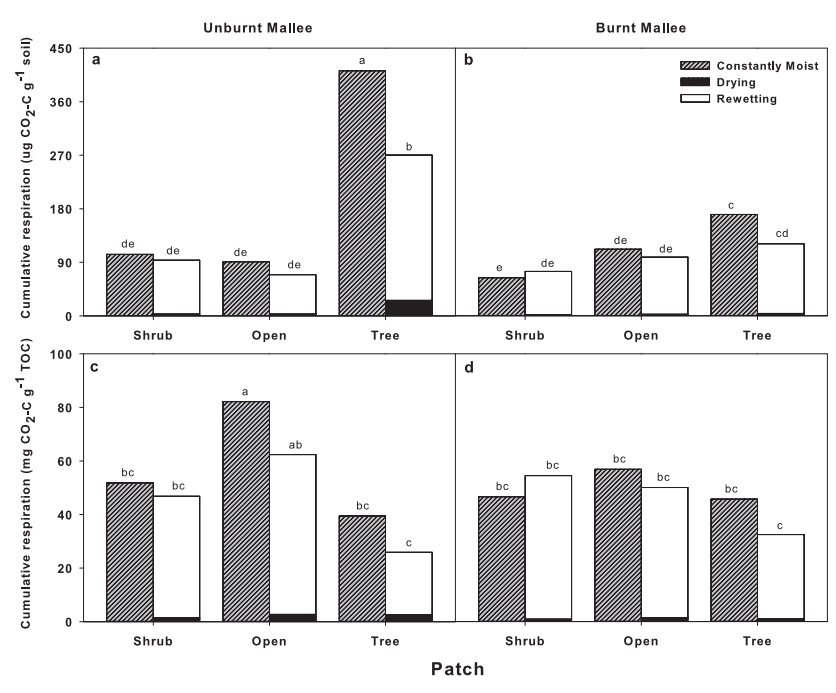

Figure 2. Cumulative respiration per gram of soil (a and $\mathbf{b})$ and per gram of TOC (c and d) in constantly moist and drying-rewetting (9day dry and 10-day moist) soils from unburnt (a, c) and burnt (b, d) mallee under shrubs, in open areas and under trees (mean, $n=4$ ).

centrations in open areas 3-fold, but had no effect on MBC concentration under shrubs.

In general, the MBC concentration at the end of the experiment was similar in CM and DRW except under trees in both unburnt and burnt mallee, where it was about $40 \%$ higher in DRW than CM. Burning only influenced the MBC concentration under trees of both CM and DRW soils, reducing it by about $60 \%$. 

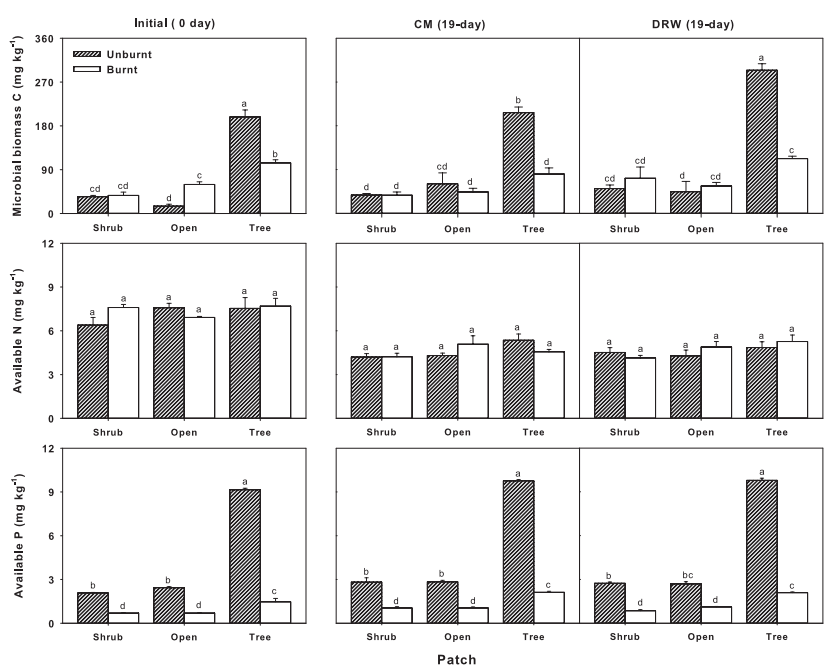

Figure 3. Soil microbial biomass $\mathrm{C}$, available $\mathrm{N}$ and $\mathrm{P}$ in soil under shrubs and trees or in open areas of unburnt and burnt mallee woodlands at the start (initial) and end of the experiment in constantly moist (CM) and drying-rewetting (DRW) treatments (mean \pm standard error, $n=4$ ). Different letters indicate significant differences for the three-way interaction burning $\times$ patch $\times$ moisture treatment interaction at $p<0.05$.

\subsection{Nutrient availability}

The available $\mathrm{N}$ concentration decreased from the start to the end of the experiment (Fig. 3). The available $\mathrm{N}$ concentration did not differ among patches and was not affected by fire or moisture regime (Fig. 3, Table A1).

The available $\mathrm{P}$ concentration was 2- to 3 -fold higher under trees than under shrubs and in open areas (Fig. 3, Table A1). It was about 3 times lower in burnt than unburnt soils, particularly under trees, but did not differ between CM and DRW.

\section{Discussion}

This study showed that the effect of drying and rewetting differed among vegetation patches and open areas in a native semi-arid woodland. Expressed per gram of TOC, the flush of respiration upon rewetting and cumulative respiration was greater in open areas or under shrubs than under trees. The recent wildfire reduced TOC and $\mathrm{MBC}$ concentrations and cumulative respiration only under trees.

\subsection{Initial soil properties (patch and fire effect)}

Concentrations of TOC, MBC and available nutrients in mallee are generally low compared to Australian agricultural soils (Hazelton and Murphy, 2007; Butterly et al., 2010), which indicates that this ecosystem is nutrient-limited. This is likely due to the dry climate and low nutrient and water retention capacity of sandy mallee soils (Nulsen et al., 1986; Macumber, 1990).

The greater TOC and MBC concentration under trees compared to the other patches (Table 1 and Fig. 3) is mainly due to greater OC input by trees (e.g. Gallardo and Schlesinger, 1992; Jobbagy and Jackson, 2000; White et al., 2009; De Deyn et al., 2008). That the available $P$ concentrations under trees are 3-fold higher than other patches is in agreement with previous studies (e.g. Facelli and Brock, 2000; Casals et al., 2014) and can be explained by the greater litter input and translocation of $\mathrm{P}$ by roots from deeper soil horizons or surrounding area.

Burning reduced TOC and MBC concentrations only under trees by about $50 \%$, whereas burning increased TOC and $\mathrm{MBC}$ in open areas. A positive correlation between TOC and MBC concentration is well known (e.g. Banu et al., 2004; Kaiser et al., 1992; Gallardo and Schlesinger, 1992). The loss of TOC under trees can be explained by volatilisation of OC during the fire (Hernandez et al., 1997). It is likely that the temperature during the fire was higher under trees than in the other patches since fire intensity is enhanced by high fuel load, i.e. organic matter content (Ursino, 2014). The increase in TOC concentration in burnt compared to unburnt open areas can be explained by wind or water erosion after the fire. Burning reduced available $\mathrm{P}$ concentrations in all patches, but not available $\mathrm{N}$ concentrations. This is not related to TOC loss with fire because that occurred only under trees. The decrease in available $\mathrm{P}$ concentrations may be due to binding of P to the charred OC (Bock et al., 2015; Laird et al., 2010).

\subsection{Effect of patch, fire and moisture in the incubation experiment}

Cumulative respiration in the CM treatment was greater under trees than in the other patches when expressed as per gram of soil, but lower when expressed per gram of TOC (Fig. 2). The greater cumulative respiration per gram of soil under trees is due to the higher TOC content under trees (Table 1), which is consistent with previous studies and can be explained by litter fall (Gallardo and Schlesinger, 1992; Wang et al., 2003). However, the lower cumulative respiration expressed per gram of TOC indicates that OC under trees was less decomposable than in the other patches (Fig. 2). This may be due to the nature of the eucalyptus leaves, which have a thick waxy cutin layer and are therefore hydrophobic and contain compounds that inhibit microbial activity (Canhoto and Graça, 1996; Borken and Matzner, 2009).

Cumulative respiration per gram of soil in DRW and CM was greater under trees than under shrubs and in open areas (Fig. 2), and this was also true for the flush of respiration upon rewetting (data not shown). This confirms the first hypothesis (that the flush of respiration after rewetting will be greater in patches with greater TOC concentration). However, the hypothesis is not supported when respiration is expressed per gram of TOC because the flush of respiration per 
gram of TOC was greater in open areas and under shrubs than under trees (Fig. 1 and Table 2). This supports the argument that OC availability is lower under trees. The flush of respiration after rewetting has been shown to be positively correlated with OC content (Butterly et al., 2010), but particularly with active OC (Franzluebbers et al., 2000). The latter and our results indicate the importance of OC availability and decomposability for the respiration flush.

Burning reduced the flush of respiration per gram of TOC in the open areas and under shrubs which suggests that burning reduced OC decomposability (Fig. 1 and Table 2). However, this was not the case under trees. The fire may have reduced OC decomposability under shrubs and in open areas through charring (Guerrero et al., 2005; Hatten and Zabowski, 2009). The low decomposability of OC under trees was apparently not further decreased by burning. We reject the second hypothesis (that burning will reduce soil respiration in all patches irrespective of moisture treatment) because burning reduced cumulative respiration per gram of soil only under trees and cumulative respiration per gram of TOC only in open areas (Fig. 2).

Although a respiration flush occurred upon rewetting, the effect of DRW on cumulative respiration compared to $\mathrm{CM}$ was inconsistent, ranging from no effect to a reduction (Fig. 2, Table 2). The former indicates that the flush of respiration upon rewetting can compensate for the low respiration during the dry period (Birch, 1958; Chowdhury et al., 2011; Borken and Matzner, 2009). However, the lower cumulative respiration in DRW compared to CM shows that this is not always the case.
DRW also had little effect on MBC concentration and no effect on $\mathrm{N}$ and $\mathrm{P}$ availability at the end of the experiment. At the end of the experiment (day 19), the MBC concentration differed between CM and DRW only under trees in the unburnt areas and the moisture treatment. It is possible that these parameters differed between DRW and CM just after rewetting. For example, Butterly et al. (2011) showed a short flush of available $\mathrm{P}$ after rewetting. However, after 2 days, available $\mathrm{P}$ concentrations did not differ between DRW and CM.

\section{Conclusion}

The small and transient effect of DRW on the measured parameters suggests that DRW events will have little impact on nutrient cycling in the semi-arid woodland. Similarly, burning only had a limited effect on nutrient availability and soil respiration. This may be due to the low nutrient availability in the sandy mallee soils. To better understand the role of DRW and burning on soil $\mathrm{C}$ flux at an ecosystem scale, field measurements are required which account for the relative sizes and therefore contributions of the different patches. 


\section{Appendix A}

Table A1. Outputs of two-way or three-way analysis of variance (ANOVA) analyses of effects of burning (unburnt and burnt), patch (under shrubs, in open areas and under trees) and treatments (constantly moist or drying-rewetting) on cumulative respiration per soil, cumulative respiration per gram of TOC, soil respiration rate on day 1 after rewetting soil, ratio of cumulative respiration per gram of TOC in DRW to that in the $\mathrm{CM}$ treatment, $\mathrm{MBC}$ and available $\mathrm{N}$ and $\mathrm{P}$ (day 0 and day 19 ).

\begin{tabular}{|c|c|c|c|c|c|c|c|}
\hline & Burning & Patch & Treatment & $\begin{array}{r}\text { Burning } \times \\
\text { patch }\end{array}$ & $\begin{array}{c}\text { Burning } \times \\
\text { treatment }\end{array}$ & $\begin{array}{c}\text { Patch } \times \\
\text { treatment }\end{array}$ & $\begin{array}{r}\text { Burning } \times \text { patch } \\
\times \text { treatment }\end{array}$ \\
\hline & $p$ & $p$ & $p$ & $p$ & $p$ & $p$ & $p$ \\
\hline Soil respiration rate on day 1 after rewetting & $<0.001$ & $<0.001$ & $<0.001$ & $<0.001$ & 0.004 & $<0.001$ & 0.002 \\
\hline Cumulative respiration per soil on day 19 & $<0.001$ & $<0.001$ & $<0.001$ & $<0.001$ & 0.003 & $<0.001$ & 0.021 \\
\hline Cumulative respiration per gram of TOC on day 19 & $<0.001$ & $<0.001$ & 0.015 & 0.002 & 0.136 & 0.158 & 0.746 \\
\hline $\mathrm{pH}$ & 0.028 & 0.008 & - & $<0.001$ & - & - & - \\
\hline TOC & $<0.001$ & $<0.001$ & - & $<0.001$ & - & - & - \\
\hline \multicolumn{8}{|l|}{ MBC } \\
\hline Day 0 & 0.020 & $<0.001$ & - & $<0.001$ & - & - & - \\
\hline Day 19 & $<0.001$ & $<0.001$ & 0.001 & $<0.001$ & 0.909 & 0.011 & 0.064 \\
\hline \multicolumn{8}{|l|}{ Available N } \\
\hline Day 0 & 0.538 & 0.412 & - & 0.150 & - & - & - \\
\hline Day 19 & 0.604 & 0.019 & 0.891 & 0.138 & 0.595 & 0.882 & 0.238 \\
\hline \multicolumn{8}{|l|}{ Available P } \\
\hline Day 0 & $<0.001$ & $<0.001$ & - & $<0.001$ & - & - & - \\
\hline Day 19 & $<0.001$ & $<0.001$ & 0.401 & $<0.001$ & 0.939 & 0.690 & 0.649 \\
\hline
\end{tabular}


Author contributions. Q. Sun, P. Marschner and W. S. Meyer designed the experiment and Q. Sun carried it out. Q. Sun, G. Koerber and W. S. Meyer performed field soil sampling. Q. Sun and P. Marschner prepared the manuscript with contributions from all co-authors.

Acknowledgements. This work was partly supported by grants from the Australian government's Terrestrial Ecosystems Research Network (TERN) (www.tern.org.au). TERN is a research infrastructure facility established under the National Collaborative Research Infrastructure Strategy and Education Infrastructure Fund, Super Science Initiative, through the Department of Industry, Innovation, Science, Research, and Tertiary Education. We greatly appreciate the support and assistance from the Australian Landscape Trust that facilitated access to the site at Calperum Station and particularly to Grant Whiteman and Peter Cale. Q. Sun's postgraduate research at the University of Adelaide was supported by a scholarship from the Chinese Scholarship Council.

Edited by: Y. Kuzyakov

\section{References}

Anderson, J. and Ingram, J.: Tropical soil biology and fertility: A handbook of methods, 2nd Edn., CAB international Wallingford, UK, 1993

Banu, N. A., Singh, B., and Copeland, L.: Soil microbial biomass and microbial biodiversity in some soils from New South Wales, Australia, Aust. J. Soil. Res., 42, 777-782, doi:10.1071/sr03132, 2004.

Birch, H. F.: The effect of soil drying on humus decomposition and nitrogen availability, Plant Soil, 10, 9-31, doi:10.1007/bf01343734, 1958.

Bock, E., Smith, N., Rogers, M., Coleman, B., Reiter, M., Benham, B., and Easton, Z. M.: Enhanced nitrate and phosphate removal in a denitrifying bioreactor with biochar, J. Environ. Qual., 44, 605-613, doi:10.2134/jeq2014.03.0111, 2015.

Borken, W. and Matzner, E.: Reappraisal of drying and wetting effects on $\mathrm{C}$ and $\mathrm{N}$ mineralization and fluxes in soils, Glob. Change Biol., 15, 808-824, doi:10.1111/j.13652486.2008.01681.x, 2009.

Butterly, C. R., Marschner, P., McNeill, A. M., and Baldock, J. A.: Rewetting $\mathrm{CO}_{2}$ pulses in Australian agricultural soils and the influence of soil properties, Biol. Fert. Soils, 46, 739-753, doi:10.1007/s00374-010-0481-9, 2010.

Butterly, C. R., McNeill, A. M., Baldock, J. A., and Marschner, P.: Rapid changes in carbon and phosphorus after rewetting of dry soil, Biol. Fert. Soils, 47, 41-50, doi:10.1007/s00374-010-0500$\mathrm{x}, 2011$.

Canhoto, C. and Graça, M. S.: Decomposition of Eucalyptus globulus leaves and three native leaf species (Alnus glutinosa, Castanea sativa and Quercus faginea) in a Portuguese low order stream, Hydrobiologia, 333, 79-85, doi:10.1007/BF00017570, 1996.

Casals, P., Romero, J., Rusch, G., and Ibrahim, M.: Soil organic C and nutrient contents under trees with different functional char- acteristics in seasonally dry tropical silvopastures, Plant Soil, 374, 643-659, doi:10.1007/s11104-013-1884-9, 2014.

Chowdhury, N., Burns, R. G., and Marschner, P.: Recovery of soil respiration after drying, Plant Soil, 348, 269-279, doi:10.1007/s11104-011-0871-2, 2011.

De Deyn, G. B., Cornelissen, J. H., and Bardgett, R. D.: Plant functional traits and soil carbon sequestration in contrasting biomes, Ecol. Lett., 11, 516-531, doi:10.1111/j.14610248.2008.01164.x, 2008.

Facelli, J. M. and Brock, D. J.: Patch dynamics in arid lands: localized effects of Acacia papyrocarpa on soils and vegetation of open woodlands of south Australia, Ecography, 23, 479-491, doi:10.1111/j.1600-0587.2000.tb00304.x, 2000.

Fernandez, I., Cabaneiro, A., and Carballas, T.: Carbon mineralization dynamics in soils after wildfires in two Galician forests, Soil Biol. Biochem., 31, 1853-1865, doi:10.1016/s00380717(99)00116-9, 1999.

Fierer, N. and Schimel, J. P.: Effects of drying-rewetting frequency on soil carbon and nitrogen transformations, Soil Biol. Biochem., 34, 777-787, doi:10.1016/s0038-0717(02)00007-x, 2002.

Fierer, N. and Schimel, J. P.: A proposed mechanism for the pulse in carbon dioxide production commonly observed following the rapid rewetting of a dry soil, Soil Sci. Soc. Am. J., 67, 798-805, 2003.

Forster, J. C.: Soil nitrogen, in: Methods in applied soil microbiology and biochemistry, edited by: Alef, K. and Nannipieri, P., Academic Press, London, 79-87, 1995.

Franzluebbers, A. J., Haney, R. L., Honeycutt, C. W., Schomberg, H. H., and Hons, F. M.: Flush of carbon dioxide following rewetting of dried soil relates to active organic pools, Soil Sci. Soc. Am. J., 64, 613-623, 2000.

Gallardo, A. and Schlesinger, W. H.: Carbon and nitrogen limitations of soil microbial biomass in desert ecosystems, Biogeochemistry, 18, 1-17, 1992.

Guerrero, C., Mataix-Solera, J., Gomez, I., Garcia-Orenes, F., and Jordan, M. M.: Microbial recolonization and chemical changes in a soil heated at different temperatures, Int. J. Wildland Fire, 14, 385-400, doi:10.1071/wf05039, 2005.

Hatten, J. A. and Zabowski, D.: Changes in Soil Organic Matter Pools and Carbon Mineralization as Influenced by Fire Severity, Soil Sci. Soc. Am. J., 73, 262-273, doi:10.2136/sssaj2007.0304, 2009.

Hazelton, P. A. and Murphy, B. W.: Interpreting soil test results: what do all the numbers mean?, 2nd Edn., CSIRO Publishing, Victoria, Australia, 67-105, 2007.

Hernandez, T., Garcia, C., and Reinhardt, I.: Short-term effect of wildfire on the chemical, biochemical and microbiological properties of Mediterranean pine forest soils, Biol. Fert. Soils, 25 , 109-116, doi:10.1007/s003740050289, 1997.

Isbell, R.: The Australian soil classification, CSIRO publishing, Melbourne, Australia, 2002.

Jarvis, P., Rey, A., Petsikos, C., Wingate, L., Rayment, M., Pereira, J., Banza, J., David, J., Miglietta, F., Borghetti, M., Manca, G., and Valentini, R.: Drying and wetting of Mediterranean soils stimulates decomposition and carbon dioxide emission: the "Birch effect", Tree Physiol., 27, 929-940, doi:10.1093/treephys/27.7.929, 2007. 
Jobbagy, E. G. and Jackson, R. B.: The vertical distribution of soil organic carbon and its relation to climate and vegetation, Ecol. Appl., 10, 423-436, doi:10.2307/2641104, 2000.

Kaiser, E. A., Mueller, T., Joergensen, R. G., Insam, H., and Heinemeyer, O.: Evaluation of methods to estimate the soil microbial biomass and the relationship with soil texture and organic matter, Soil Biol. Biochem., 24, 675-683, doi:10.1016/00380717(92)90046-Z, 1992.

Kim, D.-G., Vargas, R., Bond-Lamberty, B., and Turetsky, M. R.: Effects of soil rewetting and thawing on soil gas fluxes: a review of current literature and suggestions for future research, Biogeosciences, 9, 2459-2483, doi:10.5194/bg-9-2459-2012, 2012.

Kouno, K., Tuchiya, Y., and Ando, T.: Measurement of soil microbial biomass phosphorus by an anion exchange membrane method, Soil Biol. Biochem., 27, 1353-1357, doi:10.1016/00380717(95)00057-L, 1995.

Laird, D., Fleming, P., Wang, B., Horton, R., and Karlen, D.: Biochar impact on nutrient leaching from a Midwestern agricultural soil, Geoderma, 158, 436-442, doi:10.1016/j.geoderma.2010.05.012, 2010.

Lal, R.: Carbon sequestration in dryland ecosystems, Environ. Manageme., 33, 528-544, doi:10.1007/s00267-003-9110-9, 2004.

Macumber, P. G.: A review of Hydrogeology, soil and salinization in the Mallee region of Southeastern Australia, in: The Mallee Lands: a conservation perspective, edited by: Noble, J. C., Joss, P. J., and Jones, G. K., CSIRO Publications, Victoria, Australia, 99-105, 1990.

Miranda, K. M., Espey, M. G., and Wink, D. A.: A rapid, simple spectrophotometric method for simultaneous detection of nitrate and nitrite, Nitric Oxide-Biol. Ch., 5, 62-71, 2001.

Navarro-Garcia, F., Casermeiro, M. A., and Schimel, J. P.: When structure means conservation: Effect of aggregate structure in controlling microbial responses to rewetting events, Soil Biol. Biochem., 44, 1-8, doi:10.1016/j.soilbio.2011.09.019, 2012.

Nulsen, R. A., Bligh, K. J., Baxter, I. N., Solin, E. J., and Imrie, D. H.: The Fate of Rainfall in a Mallee and Heath Vegetated Catchment in Southern Western Australia, Aust. J. Ecol., 11, 361-371, doi:10.1111/j.1442-9993.1986.tb01406.x, 1986.

Rayment, G. E. and Higginson, F. R.: Australian laboratory handbook of soil and water chemical methods, Inkata Press, Melbourne, 1992.
R Development Core Team: R: A language and environment for statistical computing, R Foundation for Statistical Computing, Vienna, Austria, available at: http://www.R-project.org (last access: 26 August 2015), 2013.

Schlesinger, W. and Pilmanis, A.: Plant-soil Interactions in Deserts, Biogeochemistry, 42, 169-187, doi:10.1023/A:1005939924434, 1998.

Setia, R., Marschner, P., Baldock, J., Chittleborough, D., and Verma, V.: Relationships between carbon dioxide emission and soil properties in salt-affected landscapes, Soil Biol. Biochem., 43, 667674, doi:10.1016/j.soilbio.2010.12.004, 2011.

Soil Survey Staff: Keys to Soil Taxonomy, 7th Edn., US Department of Agriculture, Natural Resources Conservation Service, Washington DC, 1996.

Ursino, N.: Eco-hydrology driven fire regime in savanna, J. Theor. Biol., 355, 68-76, doi:10.1016/j.jtbi.2014.04.002, 2014.

Vance, E. D., Brookes, P. C., and Jenkinson, D. S.: An Extraction Method for Measuring Soil Microbial Biomass-C, Soil Biol. Biochem., 19, 703-707, 1987.

Walkley, A. and Black, I. A.: An examination of the degtjareff method for determining soil organic matter, and a proposed modification of the chromic acid titration method, Soil Sci., 37, 2938, 1934.

Wang, W. J., Dalal, R. C., Moody, P. W., and Smith, C. J.: Relationships of soil respiration to microbial biomass, substrate availability and clay content, Soil Biol. Biochem., 35, 273-284, 2003.

White, D. A., Welty-Bernard, A., Rasmussen, C., and Schwartz, E.: Vegetation controls on soil organic carbon dynamics in an arid, hyperthermic ecosystem, Geoderma, 150, 214-223, doi:10.1016/j.geoderma.2009.02.011, 2009.

Wilke, B.-M.: Determination of chemical and physical soil properties, in: Monitoring and Assessing Soil Bioremediation, edited by: Margesin, R. and Schinner, F., Soil Biology, Springer, Berlin, Heidelberg, 47-95, 2005.

$\mathrm{Xu}$, L., Baldocchi, D. D., and Tang, J.: How soil moisture, rain pulses, and growth alter the response of ecosystem respiration to temperature, Global Biogeochem. Cy., 18, GB4002, doi:10.1029/2004gb002281, 2004. 